Review

\title{
Iberian atmospheric dynamics and large forest fires in mainland Portugal
}

\author{
F. Ferreira-Leite ${ }^{\mathrm{a}}$, N. Ganho ${ }^{\mathrm{b}}$, A. Bento-Gonçalves ${ }^{\mathrm{c}, *}, \mathrm{~F}$. Botelho ${ }^{\mathrm{d}}$ \\ a Centro de Estudos em Geografia e Ordenamento do Território (CEGOT), Universidade do Minho, Campus de Azurém, 4800-058 Guimarães, Portugal \\ b Centro de Estudos em Geografia e Ordenamento do Território (CEGOT), Departamento de Geografia e Turismo, Universidade de Coimbra, Largo da Porta Férrea, 3004- \\ 530 Coimbra, Portugal \\ c Centro de Estudos em Geografia e Ordenamento do Território (CEGOT), Departamento de Geografia, Universidade do Minho, Campus de Azurém, 4800-058 Guimarães, \\ Portugal \\ d Centro de Estudos em Geografia e Ordenamento do Território (CEGOT), Universidade de Coimbra, Largo da Porta Férrea, 3004-530 Coimbra, Portugal
}

\section{A R T I C L E I N F O}

\section{Keywords:}

Large forest fires

Atmospheric dynamics

Synoptic type

Management tool

\begin{abstract}
A B S T R A C T
In Portugal the natural cycle of fire has been reduced, fires have become recurrent, their intensity and expansion have increased, and they have taken on catastrophic proportions.

From 2003 to 2012, were accounted, for Portuguese mainland territory, 31 "large forest fires" (LFF) larger than 5000 ha (12 of them with an area exceeding 10,000 ha), and these always occurred in the months from July to September.

Although the relationship between atmospheric dynamics, certain synoptic situations and the occurrence of LFF is already known in Portugal, several authors tried to identify the most favorable, in the new fire reality, that can even configure the existence of a new fire regime in Portugal, it is essential to identify synoptic patterns associated with LFF (5000 ha above), which could be an important meteorological tool in the management of wildfires.
\end{abstract}

\section{Introduction}

Wildland fires are a disaster phenomenon that can range from an initial attack fire, which can be managed quickly and effectively with minimum losses, to a large forest fires, which can be sometimes unbeatable and can cause major catastrophic situations (Ferreira-Leite et al., 2016).

The reasons behind large forest fires may be as diverse as the cultures, economies, histories, and ecosystems as the countries within which they occur and they have always existed, on a worldwide scale, even in locations that have climates less propitious for this occurrence, such as Alaska, Canada or Siberia (Rebelo, 1996) and they are a recurring problem in some countries, for instance, in Australia and the USA. However, although this is a global problem both due to space distribution and its evolution with time, there is no universal definition for "large forest fire" (LFF) in national or international literature as this concept usually varies from country to country (Viegas, 1998). Indeed, there are various criteria in literature to define a LFF, but the most common one used is to consider classes of fire dimension in terms of burnt area. In Europe, fires larger than 100 ha (Bermudez et al., 2009), 500 ha (Moreno et al., 1998) or 1000 ha (Piñol et al., 1998; Viegas,
1998) are generally considered LFF. In Portugal, for purely statistical reasons, the National Forestry Authority - NFA (now Institute for Nature Conservation and Forestry - INCF) defined LFF as fires that burnt an area greater than 100 ha. $^{1}$

However, if in statistical terms the criterion for dimension is important, in operational, environmental or human terms, the duration, extension (when higher than the average for the region where it occurs), the intensity of the fire (which can impede its control), the severity (which can cause serious environmental damage), the place where it occurs (which can put people's lives and goods into danger wildland-urban interfaces), the means involved, the number of deaths, the damages or even the speed of the spreading of the flames, among others, seem to be fundamental elements to take into account in a definition of LFF.

Regardless of the questions raised above and upon which some attention should be given, nevertheless considered secondary in this work, the truth, however, is that the exceptional records of fires in the last few years, for example 1978/79 and 1994 in Spain; 1998, 2000 and 2007, in Greece; 2003 and 2005, in Portugal and 2003 a little all over Europe, helped to highlight the importance of LFF (understood as fires with large dimensions in terms of burnt area) in Mediterranean

\footnotetext{
* Corresponding author.

E-mail address: bento@geografia.uminho.pt (A. Bento-Gonçalves).

${ }^{1}$ In the 70's of the past century, the then called Direção Geral das Florestas (General Directorate of Forests) considered fires the burnt area of which was higher than 10 ha as LFF (Cunha and Bento-Gonçalves, 1994).
} 
Southern Europe (Oliveras et al., 2009; Piñol et al., 1998; Pausas, 2004; Xanthopoulos, 2007).

The understanding of the factors that govern the incidence and propagation of LFF is, therefore, essential to support effective planning in the mitigation and fight against fires (Cunha and Bento-Gonçalves, 1994). The incidence and size of the fires is naturally influenced by a series of factors, from which we want to particularly highlight in this work, the atmospheric dynamics and synoptic situations that may be associated to the occurrence of LFF of larger dimension (with more than 5000 ha of burnt area) that occurred in the last decade (2003-2012).

Although fire has shaped Mediterranean ecosystems, fire occurrence schemes, meaning, their frequency and intensity, have changed (Ferreira-Leite et al., 2013). The natural cycle of fire has been reduced (Pereira et al., 2006), fires have become recurrent (Ferreira-Leite et al., 2011), their intensity (Bento-Gonçalves et al., 2012) and expansion have increased, and they have taken on catastrophic proportions and have lost their role as catalysts of the renewal of ecosystems (Noss et al., 2006).

The Mediterranean type of pluviometric systems, in which quite large aestival conditions of high temperatures and scarcity of precipitation are joined together and correspond to the necessary conditions (but not sufficient) for the emergence and propagation of forest fires, which frequently constitute large forest fires (LFF), according to their duration and the extension of the burnt area. In Mainland Portugal, between the years 2003 and 2012, 31 fires with these features were itemized, all of which occurred in 82 days in the months of July, August and September, precisely those in which there are usually more favourable weather conditions for the emergence and propagation of fire. Although during the Summer, on the Atlantic front of the Iberian Peninsula, the atmospheric conditions are nearly always favourable to the outbreak of forest fires, excepting some (very few) days in which precipitation occurs, there are periods in which these conditions are particularly propitious, more than on other days. Underlying this interdiurnal, intraestival and interaestival variation, there is a whole diversity of types of weather (Ganho, 1991), imposed by a diversity of synoptic conditions (Nash and Johnson, 1996) overlying interdiurnal variations of the regional atmospheric dynamics, especially in the low troposphere and in its interaction with geographical factors that intervene regionally and locally in the territory of mainland Portugal. Among these types of weather are the ones that determine higher risk factors of forest fires, which correspond to periods with higher temperatures joined with lower levels of relative humidity, restricted to the inland regions or generally occurring all over the territory, including the west coast, where they are less frequent, but where wind is almost always stronger and more constant. Everything depends on the physiognomy of the pressure field and the direction and speed of the flows on the surface, of the thermodynamic vertical state of the troposphere and the vertical movements of air, the origin, trajectory and characteristics of air masses that invade the territory.

It is the iberian atmospheric dynamics and the related synoptic conditions that are in force during the period in which the itemized LFF occur in the period examined which are analysed, classified and characterised, from the point of view of the regional atmospheric dynamics, the climate-meteorological consequences and the frequency of the occurrence, with the main objective of applying prevention of the risk of forest fires.

\section{Material and methods}

\subsection{Background}

In Portugal there are not many known written documents regarding forest fires before the 20th century, but we can highlight some of the existing reports: Silva and Batalha (1859) mention that the Mata Nacional de Leiria (Leiria's National Forest) was affected by various fires between 1806 and 1824, the last of which is said to have been large
(5000 ha); also Pinto, in his work "O Pinhal do Rei" (The King's Pinewood) - 1939, reports that a forest fire in 1824 consumed about 5000 ha in the referred Mata Nacional de Leiria; in the 19th century still, in 1882-1883, a large fire is said to have occurred in the "Matta do Bussaco" (Bussaco Wood), mentioned by Navarro (1884) in his book "Quatro dias na serra da Estrela" (Four days in Serra da Estrela).

Although there are no direct references to forest fires during the French Invasions (1807-1814), the policy of "burnt land" practised at the time, may have implied the existence of many fires, some of which may have been large in dimension.

More recently, in the 60's of the 20th century, after the LFF of the Vale do Rio (Leiria, Figueiró dos Vinhos) in 1961 (Lourenço, 2009), the Plano Nacional de Defesa da Floresta contra Incêndios (National Plan Against Forest Fires) - APIF, 2005 - refers the occurrence of three LFF: in Viana do Castelo (in the year of 1962), in Boticas (in the year of 1964) and in Sintra (in the year of 1996). If the fire in Sintra (6-12 of September, 1966) which consumed 5000 ha is well documented, due to the fact that it harvested the lives of 25 soldiers, the other two were never studied properly, the only reference being what Quintanilha et al. (1965) said in relation to the fire in Viana do Castelo: "From 1960, in the Forest Perimeters, the amount of damages was processed at an alarming rate $\left(2500,4000\right.$ and $9500 \operatorname{contos}^{2}$ that year and the two years following) and only in 1962, in a single fire and besides all the efforts, almost 5000 ha of wood was burnt and the inoperability of the attack was felt when the fire reached a certain size".

Despite these reports, until the 70's of the past century, fires were not considered a key-problem for the Portuguese forest. From that date on, an increase in the accumulation of fuel in forests was seen, due to the reduction of pastureland and the lack of bushes for the bed of the cattle, caused by the rural exodus that started around the 50's, which reflected closely the socioeconomic changes in course in the countries of Southern Europe, in particular of the Mediterranean region (Lourenço, 1991; Vélez, 1993; Moreno et al., 1998; Rego, 2001). These changes in the traditional use of land and lifestyle of the population implied an increase of large abandoned areas of former farm land, which on one hand, led to the recovery of the vegetation and the increase of accumulated fuel in the tradition forest spaces (Lourenço, 1991; Rego, 1992; García-Ruiz et al., 1996; Roxo et al., 1996) and, on the other hand, it led naturally to an increase of spaces with forest use. Areas with marginal productive farming were converted into forest plantations or abandoned to the natural process of ecological succession and thus converted into woods and forests, like what happened in other regions in Southern Europe (Pausas, 1999; Moreno, 1999; Lloret et al., 2002; Mouillot et al., 2003). Many of these rural areas became landscapes propitious to the occurrence of intense fires due to the high levels of biomass, accumulated throughout the years and ready to feed catastrophic fires during the summer.

Thus, forest fires with an area equal or higher than 100 ha started being "vulgarized" and, although until the 80 's of the last century, the fires in our country never reached 10000 ha of burnt area in just one occurrence, after the first one happened, in 1986, in the municipality of Vila de Rei (Lourenço, 1986), we can say that a new reality started with regard to large fires.

\subsection{Data}

In an attempt to assess the importance of LFF within number of occurrences and total burnt area, we observed that these have been of significant importance in the last three decades, mainly regarding the forest area (scrubland and settlements) that they burn (Photo 1 and 2).

Based on the statistics of fires made available by ICNF (2012), it is evident that in the 1983-1992 decade LFF represented 1.3\% of the total occurrences of forest fires (larger than 1 ha) recorded in those 10 years,

\footnotetext{
${ }^{2}$ Portuguese currency at the time.
} 

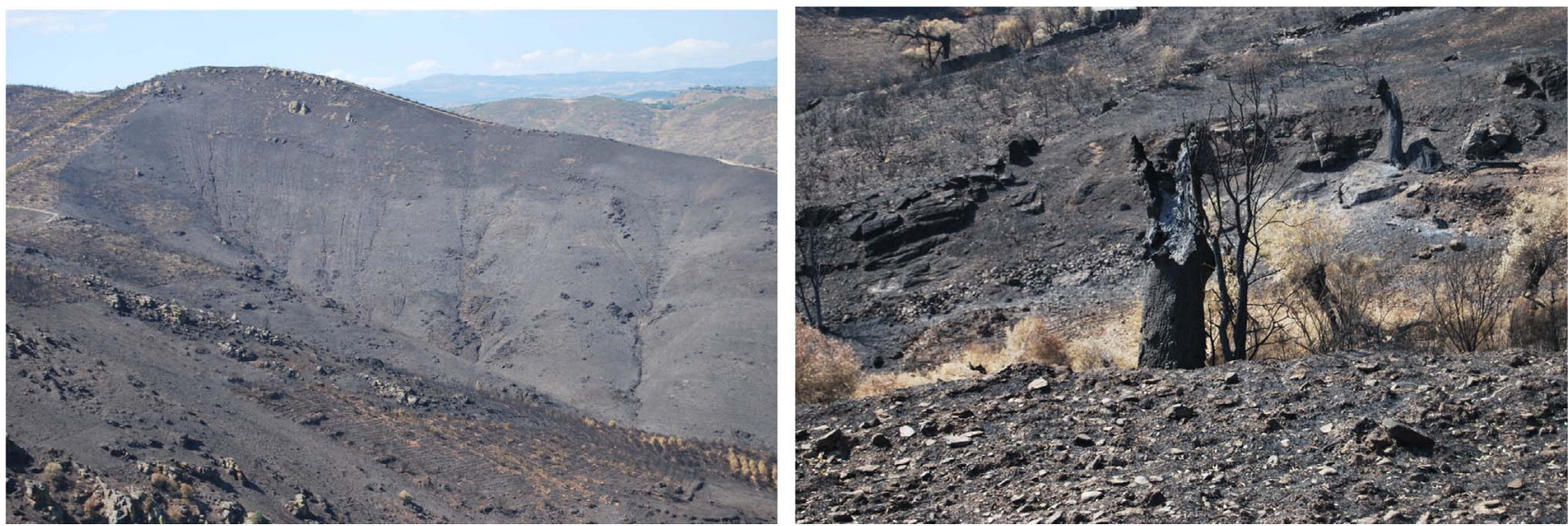

Photos 1 and 2. Large Forest Fire in Portugal (Photos: A. Bento-Gonçalves).

Table 1

Occurrences and burnt area of forest fires and large forest fires in Mainland Portugal, by decade.

Source: INCF, 2012.

\begin{tabular}{|c|c|c|c|c|c|c|}
\hline & Occurrences (no.) & Burnt Area (ha) & LFF Occurrences (no.) & LFF Occurrences (\%) & LFF Burnt Area (ha) & LFF Burnt Area (\%) \\
\hline Decade 1983-1992 & 101,130 & 937,985 & 1348 & 1.3 & 669,741 & 71.4 \\
\hline Decade 1993-2002 & 275,300 & $1,041,649$ & 1729 & 0.6 & 658,968 & 63.3 \\
\hline Decade 2003-2012 & 241,823 & $1,416,027$ & 1598 & 0.7 & $1,122,878$ & 79.3 \\
\hline
\end{tabular}

this being the most significant amount in the last three decades $(0.6 \%$ in 1993-2002 and 0.7\% in 2003-2012) (Table 1). Even though, with regards to the burnt area, this was not the most representative decade, the $71.4 \%$ of burnt area due to LFF against $63.3 \%$ recorded between 1993 and 2002 and the $79.3 \%$ of the last decade are weighty, this last one constituting, the most significant amount of the last three decades. Thus an aspect that is important to highlight emerges, the fact that in the last ten years the large forest fires of larger dimensions were recorded, this is because although the highest percentage of occurrences of LFF were not recorded between 2003 and 2012, a larger burnt area was recorded, which means that each occurrence observed in this decade burnt more than those recorded in the previous years. This represents therefore, that although the number of large forest fires has not increased throughout the years, there has been an increase of bigger "large fires".

Due to what was referred above, we decided to analyse the particularities of the occurrences and the respective burnt areas of large forest fires in the last decade. Based on the same source (ICNF) we verified that in the last ten years as a whole, 2003 was the year that registered a larger burnt area, with large forest fires being responsible for over 395640 ha, $92 \%$ of the total burnt area, although they represented less than $1 \%$ of the occurrences ( 253 occurrences). 2005 was the year where more LFF occurrences were recorded although the burnt area was lower than in 2003 but even so it was significant, representing $85 \%$ of the total burnt area for that year (from a total of $287668 \mathrm{ha}$ ). These are in fact the most alarming years in terms of occurrences of large fires and burnt area (Fig. 1). For the maximum values reached in those two years, of burnt areas in the case of 2003, the number of occurrences in 2005 , climate conditions were a major factor, these conditions being favourable for the ignition and spreading of fires in those years $^{3}$ (Lourenço et al., 2012).

On the other hand, 2007 and 2008 were the years that registered fewer LFF, when compared to the total number of occurrences, $0.2 \%$

\footnotetext{
${ }^{3}$ LFF are dependent on a series of factors and constraints, which do not need to be listed here. However, if the climate conditions are one of the important conditions for the presence of LFF, this aspect being the one we want to highlight in this work, we need to mention the importance of managing the forest areas. The space distribution of LFF can constitute an essential tool for the identification of the main intervention areas (Lourenço et al., 2012).
}

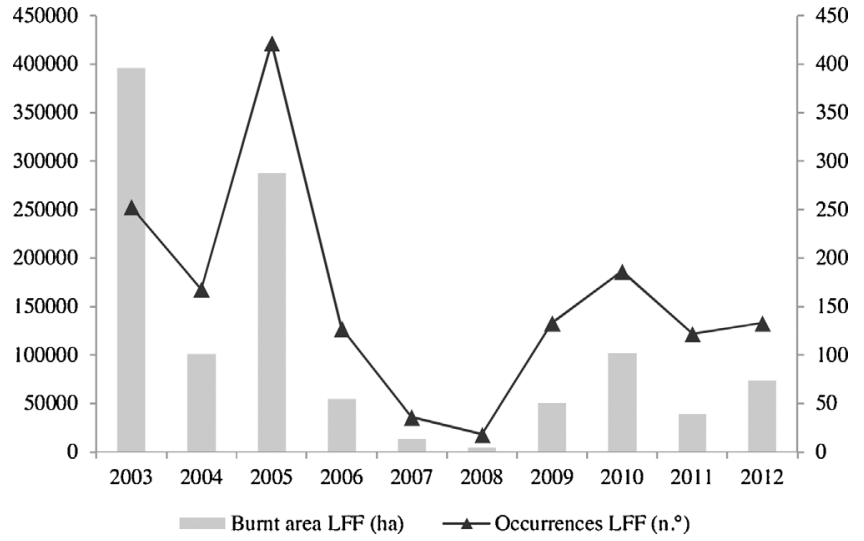

Fig. 1. LFF occurrences (no.) and burnt area (ha) through LFF, by year, between 2003 and 2012, in Mainland Portugal.

Source: INCF, 2012

(36 occurrences) and $0.1 \%$ (18 occurrences), respectively, combined with a smaller burnt area, $42.6 \%$, corresponding to 13615 ha and $25.9 \%$ (4339 ha). From 2008, the number of occurrences as well as the burnt area caused by LFF increase again, the values not overtaking, however, the values reached in 2003 and 2005.

Disaggregating the information relative to large fires in the last decade, the most frequent occurrences were the ones that burnt areas between 100 and 500 ha, representing a little over $71 \%$ of the total occurrences of LFF, these having been responsible for $22.3 \%$ of the total burnt areas by LFF in this period. The larger ones, like the ones with an area over 5.000 ha, represented $1.9 \%$ of the total occurrences and burnt $27 \%$ of the total area burnt by LFF (Table 2), confirming that in fact, in general terms, LFF represent a small fraction of the total number of fires but are responsible for a large percentage of the total burnt area.

In the context of LFF we decided to analyse the largest occurrences of LFF in closer detail, i.e., those with an area larger than 5000 ha. From the total of these occurrences, 2003 is the year that stands out, with 19 of the 31 occurrences registered, followed by 2005 with 6 occurrences with a burnt area larger than 5000 ha, followed by 2004 with 2 
occurrences. 2006, 2009 and 2010 were years that registered one occurrence, individually (Table 3 ).

In effect, 2012 and 2003 were the years that registered the largest burnt areas caused by just one fire. The maximum area registered, 24843 ha, was in the municipality of Tavira, district of Faro, dated 18 July, 2012, and 21897 ha reached in the district of Santarém, municipality of Chamusca, on 2 August, 2003.

In terms of their space distribution, the LFF that occurred in the districts of Castelo Branco, with 8 occurrences in the last decade, Faro and Santarém, with 5 occurrences each and Portalegre with 4 occurrences (Fig. 2) stand out.

\subsection{Methodologies}

In the aestival period, in the medium and high levels of the troposphere, parallel to the latitudinal filling and contraction of the circumpolar vortex, the subtropical high pressure belt moves to higher latitudes, covering the subtropical regions, especially those of the western fronts of the continents and the eastern fronts of the oceans, in the subsidence flows that characterize them. These aerological shelter conditions in zonal flow (Abz), or in meridian flow (Abm) in ridge of the Iberian area or in cut-off high, make more difficult the penetration of the polar front disturbances (Pfp) or the cut-off low disturbances (Pgf) that generate a sufficiently thick convection to originate episodes of significant precipitation in these subtropical regions where the Iberian Peninsula is and naturally Mainland Portugal. At this time of year, the disturbances in the fronts that now and then sweep through the country, do so in anticyclone margin, inhibitor of descents and the unstableness determined by possible cut-off low disturbances is mitigated by the fast tropicalization of polar air in all levels of the troposphere.

The zonal continuity of subtropical high pressure in altitude is replaced, in the low troposphere by dynamic anticyclonic cells that are hot or mixed when polar air is injected in their eastern flank. These are classified in this concrete case from the space that includes East Atlantic, Europe and the Mediterranean, in relation to the location of their nucleus, physiognomy and internal structure, in different types of anticyclones (Ramos, 1986, 1987; Ganho, 1991), in the direct dependency of the circulation system of the circumpolar flow in medium to high levels of the troposphere, at medium latitude. The referred classification of Atlantic or European anticyclones, distinguishes the following: Subtropical Atlantic Anticyclone (As) - commonly known as Azores High -, Heterogeneous Atlantic Anticyclone (Aa), Heterogeneous Atlantic Anticyclone with Polar Ridge (Ap), Heterogeneous Atlantic Anticyclone spreading through Western Europe (Ao), or European Anticyclone (Ae). It also takes into consideration three more anticyclones, namely: Heterogeneous Atlantic Anticyclone linked to the European thermal anticyclone (At), which was not taken into consideration here due to the fact that the European thermal anticyclone does not exist during the Summer and the Iberian-Mediterranean Anticyclone (Am) and African-Iberian Anticyclone (Ai), both centred in the Iberian Peninsula but very rare in the Summer, due to the fact that at this time of year inland Iberia inhibits the manifestation of surface anticyclogenesis.

The characteristics of anticyclogenesis and the space-time dynamics of the physiognomy of anticyclones that influence the Atlantic front of the Iberian Peninsula, condition the regional flow in the low troposphere, determining the direction and speed of flow and the characteristics of air masses that invade the territory, constituting thus one of the essential factors to comprehend the aestival weather types and their usual succession. However, only when they are considered in their interaction with the Iberian deformation of the surface pressure field of thermal origin.

As such, the strong heating of air via the base in the aestival months on the Iberian Peninsula and the strong thermal surface contrasts between this land mass and the adjacent Atlantic generates pressure fields 
Table 3

LFF Occurrences and burnt area, with dimension equal or higher to 5000 ha, between 2003 and 2012 .

Source: INCF, 2012

\begin{tabular}{|c|c|c|c|c|c|}
\hline Year & District & Municipality & Parish & Date alert & Burnt area (ha) \\
\hline 2003 & Faro & Monchique & Alferce & 2003-09-11 & 16,008 \\
\hline 2003 & Faro & Silves & Silves & 2003-08-12 & 11,703 \\
\hline 2003 & Faro & Monchique & Marmelete & 2003-08-08 & 12,342 \\
\hline 2003 & Portalegre & Nisa & São Matias & 2003-07-30 & 14,400 \\
\hline 2003 & Portalegre & Gavião & Belver & 2003-08-01 & 14,412 \\
\hline 2003 & Portalegre & Nisa & Montalvão & 2003-07-31 & 8279 \\
\hline 2003 & Portalegre & Castelo de Vide & São João Baptista & 2003-07-31 & 8700 \\
\hline 2003 & Beja & Odemira & Saboia & 2003-09-12 & 9317 \\
\hline 2003 & Castelo Branco & Vila Velha de Ródão & Vila Velha de Ródão & $2003-08-03$ & 5000 \\
\hline 2003 & Castelo Branco & Oleiros & Orvalho & 2003-07-29 & 9018 \\
\hline 2003 & Castelo Branco & Oleiros & Isna & 2003-08-01 & 10,800 \\
\hline 2003 & Castelo Branco & Vila de Rei & Fundada & $2003-07-30$ & 8720 \\
\hline 2003 & Castelo Branco & Sertã & Ermida & 2003-08-02 & 10,021 \\
\hline 2003 & Castelo Branco & Castelo Branco & Almaceda & 2003-07-28 & 5110 \\
\hline 2003 & Castelo Branco & Proença-a-Nova & Sobreira Formosa & 2003-08-01 & 12,920 \\
\hline 2003 & Castelo Branco & Idanha-a-Nova & Proença-a-Velha & $2003-08-14$ & 5728 \\
\hline 2003 & Santarém & Mação & Envendos & $2003-08-03$ & 5627 \\
\hline 2003 & Santarém & Abrantes & São Miguel do Rio Torto & 2003-08-02 & 5900 \\
\hline 2003 & Santarém & Chamusca & Ulme & 2003-08-02 & 21,897 \\
\hline 2004 & Faro & Loulé & Alte & $2004-07-26$ & 12,807 \\
\hline 2004 & Beja & Almodôvar & São Barnabé & 2004-07-26 & 8000 \\
\hline 2005 & Guarda & Seia & Vide & 2005-07-19 & 7051 \\
\hline 2005 & Coimbra & Pampilhosa da Serra & Vidual & $2005-08-13$ & 11,707 \\
\hline 2005 & Aveiro & Arouca & Janarde & 2005-08-03 & 8556 \\
\hline 2005 & Santarém & Ourém & Urqueira & 2005-08-04 & 5650 \\
\hline 2005 & Santarém & Abrantes & Fontes & 2005-08-20 & 6694 \\
\hline 2005 & Vila Real & Vila Pouca de Aguiar & Parada de Monteiros & 2005-08-07 & 7086 \\
\hline 2006 & Viana do Castelo & Arcos de Valdevez & Carralcova & 2006-08-06 & 5590 \\
\hline 2009 & Guarda & Sabugal & Sortelha & 2009-08-30 & 7080 \\
\hline 2010 & Viseu & São Pedro do Sul & São Cristovão De Lafões & $2010-08-06$ & 5066 \\
\hline 2012 & Faro & Tavira & Cachopo & $2012-07-18$ & 24,843 \\
\hline
\end{tabular}

of thermal origin, almost permanent in character, restricted to lower levels of the troposphere which they superpose, normally above the geopotential of $850 \mathrm{hPa}$, the subtropical high pressure. This pellicular pressure field manifests itself, or as a closed Iberian low pressure area (Bif), the pressure of which does not go below 1010hPa, or with a deformation trough (Biv), covering the entire Iberian Peninsula, from the South Eastern or South flank of anticyclonic cells that influence this region. The surface synoptic flows and the type and characteristics of the air masses that are channelled to Mainland Portugal depend a lot on the position of the centre of the closed thermal low or the thermal axial trough in relation to Portuguese territory and the joint flow with the anticyclonic cells that they interact with. When the low pressure centre or axial trough position themselves further inland in the Iberian Peninsula - in Spain (esp) or inland Portugal (int) - the W-E barometric gradients over Portugal cause surface flows of NW or N, especially on the west coast, constituting the "nortada" wind system, The north wind is usually stronger and more persistent when the Iberian low pressure field interacts with the Aa or Ap anticyclones, as the intrusion of polar air in these anticyclones intensifies the barometric gradients in the Atlantic front of the Iberian Peninsula, but is also felt with the influence of the As anticyclone, or the Ao and Ae anticyclones. In these conditions advection of direct maritime polar (Pmd) or tropicalized (Pmt) air masses occurs, when dominate the Ap and Aa anticyclones, or direct continental polar (Pcd) or tropicalized (Pct) air masses, transported in the joint flow of the Iberian thermal low with the Ao or Ae anticyclones, or even the direct maritime tropical (Tmd) or continental (Tmc) air masses, channelled by the interaction between the Iberian thermal low and the As anticyclone. In the first case the ridge is developed directly for the Iberian Peninsula, in the second case with the expansion of the ridge over the Biscay Bay, France and the Iberian Peninsula. In any of these situations, when the surface barometric gradient over Portugal is weaker, the base cooling of the air masses in contact with the adjacent Atlantic, superficially cooled by the West
Iberian upwelling (Ferreira, 1984) induced by the north wind ("nortada") system gives origin to a maritime air mass. This air mass, which has pellicular features and is cool and more humid (Amp), invades the regions of the North and Centre cost of the country, especially at dawn and in the morning with a limited and variable continental penetration in relation to topography and is responsible for lower temperatures and higher relative humidity in the invaded areas than in the rest of the territory, as well as low clouds and advection fog, with morning dissipation.

The warmer weather conditions and those with greater air dryness, generalized all over Mainland Portugal, including the west coast, and that when intense and persistent constitute "heat waves", occur when or the centre of the closed thermal low or the axial trough of the thermal low, migrate to the west coast (lit), or even, when the Iberian thermal trough aggregates to the low pressure field of thermal origin in Northwest Africa, constituting itself as an African-Iberian thermal low (Bia), many times with a closed low pressure centre inside, positioned South, or South of the territory (naf). This type of physiognomy of the Iberian or the African-Iberian thermal field is usually part of the South flank of the As anticyclone, very spread out in Western Mediterranean and North Africa, or in the South flank of the Ae anticyclone or even the Ao anticyclone. Mainland Portugal is thus directly under the influence of the east flank flow of the thermal trough or of the closed thermal low, with flows at NE, E, or SE, decreasing or stopping the north wind system, causing an invasion of air mass, or Iberian Continental Tropical (Tci), or when the trajectory over Northwest Africa is sufficiently long, African Continental Tropical (Tca), the warmest and driest that flow to the Atlantic front of the Iberian Peninsula and to which higher risks of the occurrence of LFF are associated. The mitigation or disappearance of these forest fire high risk conditions occur with the substitution of the direct influence of the tropical air masses with continental trajectory through maritime air invasion on the coast, or of air masses with polar origin, recent or tropicalized, influencing the whole territory. This 


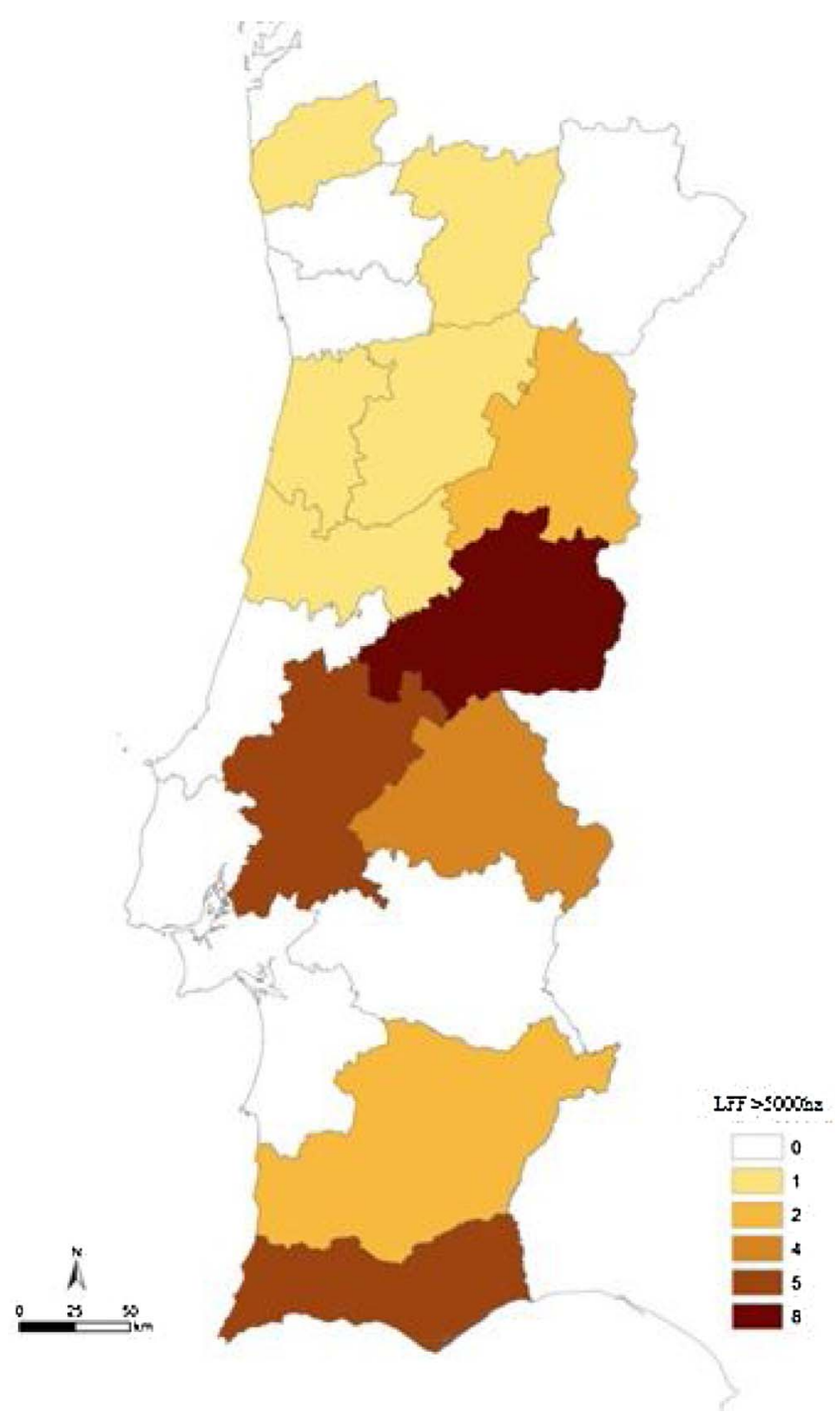

Fig. 2. LFF Occurrences $\left(\mathrm{n}^{\circ}\right)$ of dimension equal or higher than 5000 ha, by district, between 2003 and 2012, in Mainland Portugal.

Source: INCF, 2012

implies the movement eastwards, or the Iberian or African Iberian thermal axial trough, or the closed thermal low centre, with the reconstitution of the north wind system and the interruption of the direct flow from North Africa in the low levels of the troposphere. The synoptic causes for this modification in the surface pressure field pattern associated to heat waves, and which occurs in stage with zonal aerological shelter conditions (Abz) or in ridge $(\mathrm{Abc})$ in altitude, is the invasion of the medium and high levels of the Iberian troposphere through cold polar, trough (Afv) or cut-off (Afg) advection. When this polar advection in altitude overlaps the Iberian thermal low, which transforms itself into a Heterogeneous Iberian low (Bim), the vertical thermal gradient is emphasised and instability conditions are generated that are favourable to the appearance of cloud cells of vertical development and precipitation, under the form of rain or hail showers, sometimes heavy, and disperse thunderstorms, with particular incidence in the interior regions, which do not last long in the Summer, but that can help in the extinction of the forest fires.

In Table 4 there is a summary and classification of the synoptic situations that usually characterize the atmospheric dynamics in Europe, North-eastern Atlantic and the Western Mediterranean in the aestival period and that are in the basis of the diversity of the types of weather in the Summer in Mainland Portugal and in the explanation of the more or less favourable conditions for forest fires at that time of year.
Table 4

Classification of the synoptic situations.

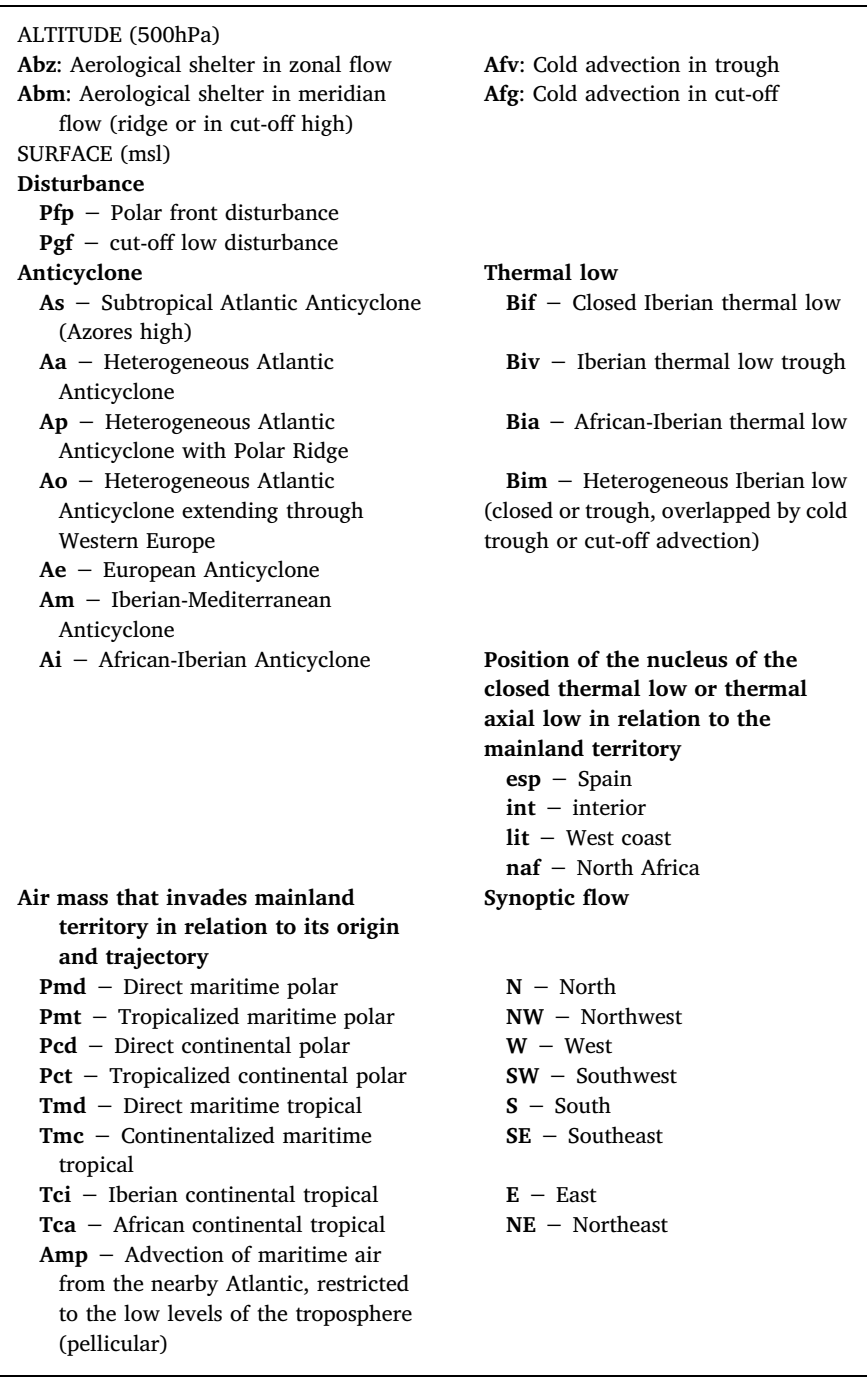

\section{Results and discussion}

Next the application of the classification of the synoptic situations itemized in Table 4 is carried out, on 82 days in the months of July, August, September of 2003 and 2012, during which 31 large forest fires were recorded and the statistical characterization, from the point of view of frequency of the occurrence in the period analyzed (Table 5).

Through the analysis you can see that in altitude (geopotential at $500 \mathrm{hPa})$, the situations of aerological shelter $(86.5 \%$ of the sample) dominate, of which $46.3 \%$ were associated to a ridge meridian flow, or related to a cut-off high, and $40.2 \%$ were associated to zonal flow. In the $13.4 \%$ of the days in which situations of aerological shelter were not observed, the occurrence of trough cold advection (11\%) or cut-off low cold advection $(2.4 \%)$ were seen, which corresponded, almost always, to synoptic situations that made the fight against forest fires and consequently their extinction easier.

If in altitude situations of aerological shelter predominated, at a surface level, as would be expected, anticyclonic conditions dominated. Resorting once again to Table 5 you can see that the Subtropical Atlantic Anticyclone (As), with $60.6 \%$ of the observations, is the predominant one, followed by the Heterogeneous Atlantic Anticyclone (Aa) and the European Anticyclone (Ae), with $21.1 \%$ and $12.7 \%$ of the observations, respectively. The Heterogeneous Atlantic Anticyclone extending through Western Europe (Ao) and Heterogeneous Atlantic 
Table 5

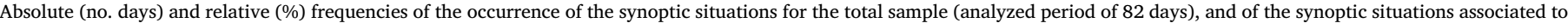
the advection of the Tca and Tci (for the sub-sample of 53 of the 82 days of the period analyzed) air masses in Mainland Portugal.

Source: Based on CFS Reanalysis (00 h UTC), Wetterzentrale archive.

\begin{tabular}{|c|c|c|c|c|c|c|c|c|c|c|}
\hline Synoptic Situations & No. days & $\%$ & Synoptic Situations & No. days & $\%$ & $\begin{array}{l}\text { Air Mass } \rightarrow \\
\text { Synoptic Situations }\end{array}$ & $\begin{array}{l}\text { Tca } \\
\text { No. days }\end{array}$ & $\%$ & $\begin{array}{l}\text { Tci } \\
\text { No. days }\end{array}$ & $\%$ \\
\hline Abz & 33 & 40.2 & $\mathbf{N}$ & 14 & 17.1 & $\mathrm{Abz}$ & 13 & 24.5 & 8 & 15.1 \\
\hline Abm & 38 & 46.3 & NW & 15 & 18.3 & Abm & 25 & 47.2 & 7 & 13.2 \\
\hline Afv & 9 & 11.0 & W & 3 & 3.7 & Afv & & & & \\
\hline \multirow[t]{5}{*}{ Afg } & 2 & 2.4 & SW & 3 & 3.7 & Afg & & & & \\
\hline & & & $S$ & 2 & 2.4 & As & 22 & 41.5 & 13 & 24.4 \\
\hline & & & SE & 6 & 7.3 & Aa & 4 & 7.6 & 2 & 3.8 \\
\hline & & & $\mathbf{E}$ & 27 & 32.9 & Ap & 3 & 5.7 & & \\
\hline & & & NE & 12 & 14.6 & Ao & & & & \\
\hline As & 43 & 60.6 & Pmd & 3 & 3.2 & Ae & 9 & 17.0 & & \\
\hline Aa & 15 & 21.1 & Pmt & 8 & 8.5 & $\mathbf{A i}$ & & & & \\
\hline Ap & 3 & 4.2 & Pcd & 0 & 0.0 & Am & & & & \\
\hline Ao & 1 & 1.4 & Pct & 6 & 6.4 & Bif & 3 & 5.7 & 6 & 11.3 \\
\hline $\mathrm{Ae}$ & 9 & 12.7 & Tmd & 7 & 7.4 & Biv & 6 & 11.3 & 5 & 9.4 \\
\hline $\mathbf{A i}$ & 0 & 0.0 & Tmc & 4 & 4.3 & Bia & 29 & 54.7 & 4 & 7.6 \\
\hline \multirow[t]{3}{*}{ Am } & 0 & 0.0 & Tci & 15 & 16.0 & Bim & & & & \\
\hline & & & Tca & 38 & 40.4 & esp & 1 & 1.9 & 5 & 9.4 \\
\hline & & & Amp & 13 & 13.8 & int & 7 & 13.2 & 2 & 3.8 \\
\hline Bif & 17 & 21.8 & & & & lit & 14 & 26.4 & 6 & 11.3 \\
\hline Biv & 23 & 29.5 & & & & naf & 16 & 30.2 & 2 & 3.8 \\
\hline Bia & 34 & 43.6 & & & & $\mathbf{N}$ & 2 & 3.8 & 4 & 7.6 \\
\hline Bim & 4 & 5.1 & & & & NW & 2 & 3.8 & 2 & 3.8 \\
\hline esp & 24 & 30.8 & & & & W & & & & \\
\hline int & 14 & 17.9 & & & & SW & & & & \\
\hline lit & 21 & 26.9 & & & & $S$ & 2 & 3.8 & & \\
\hline \multirow[t]{3}{*}{ naf } & 19 & 24.4 & & & & SE & 6 & 11.3 & & \\
\hline & & & & & & E & 20 & 37.7 & 5 & 9.4 \\
\hline & & & & & & NE & 6 & 11.3 & 4 & 7.6 \\
\hline
\end{tabular}

with Polar Ridge (Ap) had an almost residual frequency, having occurred in only $5.6 \%$ of the days analyzed.

From the analysis of the synoptic cartography of the period examined, we can see the existence of thermal low pressure in the Iberian Peninsula, with the predomination of the African-Iberian Low (43.3\%) in relation to the Trough Iberian low (29.5\%) and the Closed Iberian Low $(21.8 \%)$, the low pressure nucleus or axial trough of which, according to the case, was located in $30.8 \%$ of the observations in Spanish territory, in $26.9 \%$ on the west coast of Mainland Portugal and in $24.4 \%$ of the observations in North Africa on $95 \%$ of the days analyzed.

From the joint action of the various abovementioned action centres, according to Table 5, you can see that during the period analyzed the East synoptic flows predominate, in $32.9 \%$ of the sample, followed by the North and Northwest flows, with $17.1 \%$ and $18.3 \%$, respectively.

However, the most explanatory factor of the temperatures and the relative humidity at surface level is the type of air mass that invades the territory of Mainland Portugal. The air masses that determine the combination of higher temperatures with lower levels of relative humidity are Tca (African Continental Tropical) and Tci (Iberian Continental Tropical), precisely those the influence of which was felt in the period analyzed. The frequency of the occurrence of the Tca air mass was $46.3 \%$ of the sample and the Tci air mass was $18.3 \%$ of the sample, making up 53 days ( $64.6 \%$ of the sample) of the total 82 days considered. On the remaining 29 days (35.4\%) of the period analyzed, the influence of other air masses was observed.

Taking into consideration only the 53 days in which the Tca and Tci air masses advection dominated, the frequency of the occurrence of each one of these air masses was $71.7 \%$ and $28.3 \%$ respectively of the subsample. For this same subsample the absolute frequencies of the occurrence ( $\mathrm{n}^{\circ}$ days) and the relative frequency (\%) of the different synoptic situations subjacent or associated to the advection of each of the Tca or Tci air masses were calculated, the most relevant results of which will be analyzed (Table 5).

Crossing the data of the two most frequent air masses during the period analysed with the other synoptic situations, it can be observed the African continental tropical air mass (Tca) is associated, in about $47 \%$ of cases, to a flow of the aerological shelter in altitude of meridian character (Abm). At the surface level it is transported, in most observations carried out, by the joint flow of a subtropical Atlantic anticyclone (As) - 41.5\% - with an Iberian-African low pressure centre (Bia) $-54.7 \%-$, with the nucleus centred or in the North of Africa (naf), in $30 \%$ of days, or on the West Coast (lit), on $26.4 \%$ of days. This air mass is mainly associated to flows in the east quadrant, namely East (37.7\%), Southeast (11.3\%) and Northeast $(11.3 \%)$, which in corresponding to continental trajectories contribute to the explanation of the reduced amounts of relative humidity and high temperatures.

Although it presents a lower representativeness than the African continental tropical air mass (Tca), the Iberian continental tropical air mass (Tci) corresponds to the second most frequent. If the Tca was clearly related to situations of aerological shelter in meridian flow, Tci presents a frequency of occurrence very similar between aerological shelter in zonal flow situations $(15.1 \%)$ or in meridian flow (13.2\%). At a surface level, this air mass is associated, on most days, to the joint flow of a subtropical Atlantic Anticyclone (24.4\%) with a thermal low pressure, usually the Iberian closed type $(11.3 \%)$ or Iberian trough (9.4\%), with a centred nucleus or on the west coast of the Peninsula $(11.3 \%)$ or in Spain $(9.4 \%)$. As with Tca, this air mass is also associated to synoptic flows of the east quadrant, namely from the East $(9.4 \%)$ or Northeast $(7.6 \%)$. However, the north flows also had a statistical relevance, corresponding to $7.6 \%$ of the observations.

\section{Conclusion}

Although the number of large forest fires (LFF) has not increased throughout the years, in the last decade there has been an increase in the larger "big fires", being that fires of more than 100 ha have been vulgarized and it is expected that INCF will only consider fires larger than 100 ha as LFF for statistical purposes.

Even the bigger LFF, the ones larger than 5000 ha, although they are not considered "common" yet in Portugal, they have become part of 


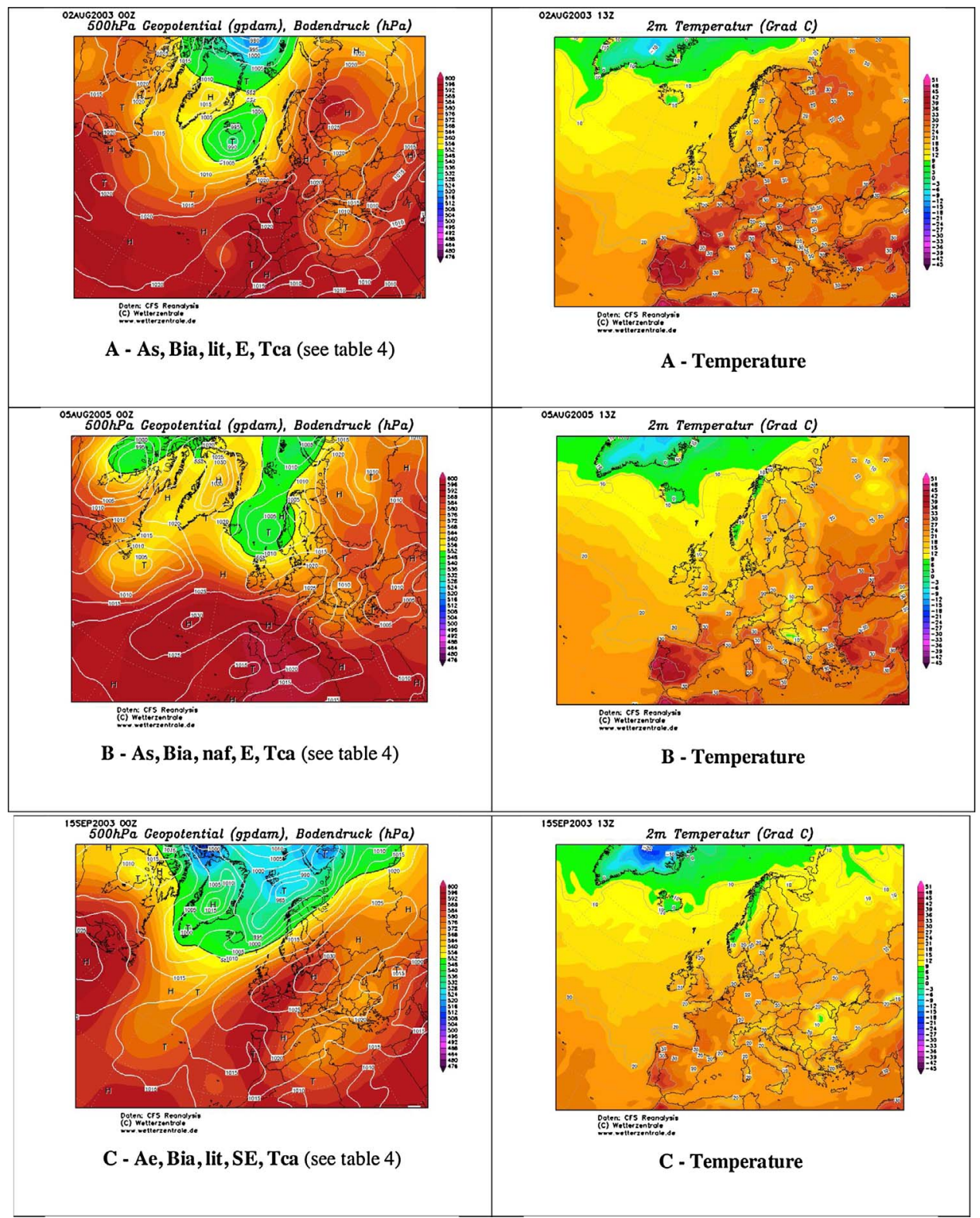

Fig. 3. Synoptic situations (left) and temperatures (right) most frequently associated to favourable conditions to large forest fires in Mainland Portugal. Source: CFS Reanalysis, Wetterzentrale archive our forest fire panorama in the last decade and as such, even though we are conscious of the complex multiplicity of factors that determine them, it is important to understand the climate-meteorological conditions associated to them.

As a conclusive synthesis of the analysis developed in the previous points, in Fig. 3(A-F) some of the $00 \mathrm{~h}$ UTC synoptic situations and $13 \mathrm{~h}$ UTC corresponding medium sea level (msl) temperatures are presented. These were selected from 82 days of the analyzed period and they are examples of the atmospheric dynamics conditions that generate the combination of the highest temperatures with the lowest levels of relative humidity and as such, they are also subjacent to the highest forest fire risks.

The synoptic patterns they illustrate, relatively similar to the East Atlantic, Europe and Western Mediterranean scales, present "nuances" at the location climate scale of the Atlantic front of the Iberian Peninsula that determine the type and characteristics, from the thermohigrometric point of view, of the lower levels of air mass that invade Portuguese territory. The crucial factor for the maintenance, during the afternoon, of high temperatures (above $35 / 40{ }^{\circ} \mathrm{C}$ ) with dry air (less than 25\%), as well as the joint flow of Atlantic or European anticyclones with aestival thermal low is the physiognomy of the thermal field. When, regardless of the type of anticyclone with which it conjugates, or the Iberian or African-Iberian thermal axial trough is located on the Portuguese coast, or in the context of this trough a low pressure nucleus is individualized immediately south of the Iberian Peninsula, the east flows transport continental tropical air masses with a predominant Iberian trajectory or with a long trajectory on the Northwest of Africa. In these low levels atmospheric dynamics conditions you can see the highest temperatures in association with the lowest values of relative humidity in Mainland Portugal, generalized inclusively at the west coast front. When the axial trough moves to the interior of the country, or the low pressure nucleus migrates to Spain, the direction of the barometric gradients on the Atlantic front of the Iberian Peninsula boosts the installation of the west Iberian north wind ("nortada") system and the advection of air masses with more moderate surface thermohigrometric characteristics, mitigating the risks of emergence and propagation of forest fires, but not enough to suppress them. Such conditions can only be observed when the regional atmospheric dynamics favours deep convection and allows the occurrence of significant precipitation, which, in the aestival period, only happens sporadically. 


\section{Acknowledgments}

This work was co-financed by the European Regional Development Fund (ERDF) through the COMPETE 2020 Operational Programe Competitiveness and Internationalization (POCI) and national funds by FCT under the POCI-01-0145-FEDER-006891 project (FCT Ref: UID/ GEO 04084/2013).

\section{References}

Agência para a Prevenção de Incêndios Florestais (APIF) e Instituto Superior de Agronomia (ISA), (2005). Plano Nacional de Defesa da Floresta Contra Incêndios Proposta Técnica, Lisboa, 208 p.

Bento-Gonçalves, A., Vieira, A., Úbeda, X., Martin, D., 2012. Fire and soils: key concepts and recent advances. Geoderma 191, 3-13.

Bermudez, Z., Mendes, J., Pereira, J.M.C., Turkman, K.F., Vasconcelos, M.J.P., 2009. Spatial and temporal extreme of wildfires sizes in Portugal. Int. J. Wildland Fire 18, 983-991.

Cunha, L., Bento-Gonçalves, A., 1994. Clima e tipos de tempo enquanto características físicas condicionantes do risco de incêndio. Ensaio Metodológico. Cadernos de Geografia 13, 3-13.

Ferreira, D.B., 1984. Le système climatique de ĺupwelling ouest Ibérique. Linha de Acção de Geografia Física, (rel. Nº 19). C.E.G., INIC, Lisboa (91p.).

Ferreira-Leite, F., Bento-Gonçalves, A., Vieira, A., 2011. The recurrence interval of forest fires in Cabeço da Vaca (Cabreira Mountain-northwest of Portugal). Environ. Res. 111 (2), 215-221.

Ferreira-Leite, F., Lourenço, L., Bento-Gonçalves, A., 2013. Large forest fires in mainland Portugal, brief characterization. Méditerranée 121, 53-66.

Ferreira-Leite, F., Bento-Gonçalves, A., Vieira, A., Nunes, A., Lourenço, L., 2016. Incidence and recurrence of large forest fires in mainland Portuga. Nat. Hazards 84 (2), 1035-1053.

Ganho, N., 1991. Contribuição para o conhecimento dos tipos de tempo de Verão em Portugal - O exemplo de Coimbra. Cadernos de Geografia 10, 431-513.

García-Ruiz, J.M., Lasanta, T., Ruiz-Flano, P., Ortigosa, L., White, S., González, C., Martí, C., 1996. Land-use changes and sustainable development in mountain areas: a case study in the Spanish Pyrenees. Landscape Ecol. 11, 267-277.

Lloret, F., Calvo, E., Pons, X., Díaz-Delgado, R., 2002. Wildfires and landscape patterns in the eastern Iberian Peninsula. Landscape Ecol. 17, 745-759.

Lourenço, L., Bento-Gonçalves, A., Vieira, A., Nunes, Adélia, Ferreira-Leite, F., 2012. Forest fires in Portugal. In: Bento-Goncalves, A., Vieira, A. (Eds.), Portugal Economic, Political and Social Issues. Nova Publishers, New York, pp. 97-111.

Lourenço, L., 1986. Consequências geográficas dos incêndios florestais nas serras de xisto do centro do país. IV Colóquio Ibérico de Geografia. Actas 943-957.

Lourenço, L., 1991. Aspectos sócio-económicos dos incêndios florestais em Portugal, vol. LXVII. Biblos, pp. 373-385.

Lourenço, Luciano (2009) Plenas manifestações do risco de incêndio florestal em serras do centro de Portugal. Efeitos erosivos, subsequentes e reabilitações pontuais, Territorium, 16, p. 5-12.

Moreno, J.M., Vazquez, A., Velez, R., 1998. Recent history of forest fires in Spain. In: Moreno, J.M. (Ed.), Large Forest Fires. Backhuys Publishers, Leiden, The Netherlands, pp. 159-185.

Moreno, J.M., 1999. Forest fires: trends and implications in desertification prone areas of Southern Europe. In: Balabanis, P., Peter, D., Ghazi, A., Tsogas, M. (Eds.) Mediterranean Desertification: Research Results and Policy Implications 1. DG Research, European Commission EUR, pp. 115-150.

Mouillot, F., Ratte, J.P., Joffre, R., Moreno, J.M., Rambal, S., 2003. Some determinants of the spatio-temporal fire cycle in a Mediterranean landscape (Corsia, France). Landscape Ecol. 18, 665-674.

Nash, C.H., Johnson, E.A., 1996. Synoptic climatology of lightning-caused forest fires in subalpine and boreal forests. Can. J. For. Res. 26 (10), 1859-1874. http://dx.doi.org/ $10.1139 / \mathrm{x} 26-211$.

Navarro, Emydgio (1884) Quatro dias na Serra da Estrella. Notas de um passeio. Porto E. da Costa Santos.

Noss, R., Franklin, W., Schoennagel, T., Moyle, P., 2006. Managing fire-prone forests in the western United States. Front. Ecol. Environ. 4, 481-487.

Oliveras, I., Gracia, M., Moré, G., Retana, J., 2009. Factors influencing the pattern of fire severities in a large wildfire under extreme meteorological conditions in the Mediterranean basin. Int. J. Wildland Fire 18, 755-764.

Pausas, J.G., 1999. Response of plant functional types to changes in the fire regime in Mediterranean ecosystems: a simulation approach. J. Veg. Sci. 10, 717-722.

Pausas, J.G., 2004. Changes in fire and climate in the eastern Iberian Peninsula (Mediterranean bassin). Clim. Change 63, 337-350.

Pereira, J., Carreiras, J., Silva, J., Vasconcelos, M., 2006. Alguns conceitos básicos sobre os fogos rurais em Portugal. Incêndios Florestais em Portugal: caracterização, impactes e prevenção. ISA Press, Lisboa, pp. 134-161.

Piñol, J., Terradas, J., Lloret, F., 1998. Climate warming and wildfire hazard and wildfire occurrence in coastal Eastern Spain. Clim. Change 38, 345-357.

Quintanilha, V., Silva, J., Silva, J.M. (1965) Princípios Básicos de Luta Contra Incêndios na Floresta Particular Portuguesa. Direcção-Geral dos Serviços Florestais e Aquícolas, Porto.

Ramos, C., 1986. Tipos de Anticiclones e Ritmo Climático de Portugal. Estudo de Climatologia. Linha de Acão de Geografia Física (rel. N 25). C.E.G., Lisboa (236 p.).

Ramos, C., 1987. A influência das situações anticiclónicas no regime da precipitação em Portugal. Finisterra 22 (43), 5-38.

Rebelo, F., 1996. Florestas e grandes incêndios florestais no mundo. Territorium 3, 5-10.

Rego, F.C., 1992. Land use changes and wildfires. In: Teller, A., Mathy, P., Jeffers, J.N.R. (Eds.), Response of Forest Fires to Environmental Change. Elsevier, London, pp. 367-373.

Rego, F.C., 2001. Florestas públicas. Direção Geral das Florestas e Comissão Nacional Especializada de Fogos Florestais, Lisboa (105 p.).

Roxo, M.J., Cortesão Casimiro, P., Soeiro de Brito, R., 1996. Inner Lower Alentejo field site: cereal cropping, soil degradation and desertification. In: Brandt, C.J., Thornes, J. (Eds.), Mediterranean Desertification and Land Use. Wiley \& Sons, Chichester, pp. 111-135.

Silva, Francisco, Batalha, Caetano (1859) Memória sobre o Pinhal Nacional de Leiria. Suas madeiras e produtos rezinosos. Associação Marítima e Colonial. Imprensa Nacional, Lisboa.

Vélez, R., 1993. High intensity forest fires in the Mediterranean Basin: natural and socioeconomic causes. Disaster Manage. 5, 16-20.

Viegas, D.X., 1998. Weather, fuel status and fire occurrence: predicting large fires. In: Moreno, J.M. (Ed.), Large Forest Fires. Backhuys Publishers, Leiden, The Netherlands, pp. 31-49.

Xanthopoulos, G., 2007. Olympic flames. Wildfire 16, 10-18. 